\title{
IMPLEMENTASI PRINSIP-PRINSIP PENDIDIKAN DALAM ISLAM
}

\author{
Martatik \\ Badan Penelitian dan Pengembangan dan Pendidikan dan Pelatihan - Kementerian Agama \\ Email: martatik75@gmail.com
}

https://doi.org/10.36052/andragogi.v7i2.91

Diterima: 8 Oktober 2019 | Disetujui: 11 Desember 2019 | Dipublikasikan: 30 Desember 2019

\begin{abstract}
Abstrak
Tujuan penelitian ini adalah untuk mendeskripsikan penerapan prinsip-prinsip pendidikan dalam Islam, serta prinsip tauhid dan implikasinya dalam pendidikan. Penelitian ini menggunakan pendekatan kualitatif dengan metode kajian literatur terhadap tafsir ayat-ayat yang berkaitan dengan pendidikan serta data lain yang mendukung penelitian ini. Hasil penelitian ini menyimpulkan bahwa, sudah saatnya umat Islam melakukan penataan kembali usaha-usaha pendidikan yang dilakukannya sejalan dengan tuntutan era global dengan berbasiskan pada Alquran. Rumusan konsep pendidikan yang berdasarkan perspektif Alquran sudah waktunya untuk disusun. Tugas dan tanggung jawab pendidik dalam melahirkan manusia yang cerdas, berakhlak mulia, berilmu, terampil, dan ramah sudah waktunya untuk dilakukan. Karena manusia-manusia yang demikian itulah yang diperlukan di era global saat ini, dan manusia itu pula yang dikehendaki oleh Alquran.
\end{abstract}

Kata Kunci: Implementasi, prinsip, pendidikan Islam, Tauhid.

\begin{abstract}
The purpose of this study is to describe the application of educational principles in Islam, as well as the principle of monotheism and their implications in education, using a qualitative approach to the literature review method of interpretation of verses relating to education as well as other data supporting this research. The results of this study conclude that, already it's time for Muslims to reorganize their educational efforts in line with the demands of the global era based on the Koran. It is time to formulate an educational concept based on the perspective of the Qur'an. The duties and responsibilities of educators in giving birth to people who are intelligent, noble, knowledgeable, skilled and friendly are time to do. Because such human beings are needed in the current global era, and that human being is also desired by the Qur'an.
\end{abstract}

Keywords: Implementation, Principles, Islamic Education, Tauhid.

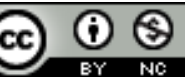

This work is licensed under a Creative Commons Attribution-NonCommercial 4.0 International License 


\section{PENDAHULUAN}

$\mathscr{P}$ endidikan memiliki peranan penting bagi ikhtiar pembangunan sumber daya manusia yang berkualitas, yang ditandai oleh adanya peningkatan kecerdasan, pengetahuan, dan keterampilan. Pendidikan memiliki peran yang sangat strategis bagi upaya-upaya peningkatan kualitas kehidupan manusia. Secara teoritis maupun secara empiris terbukti bahwa melalui pendidikan bisa dicapai perbaikan derajat kesejahteraan dan pengurangan angka kemiskinan. Pendidikan juga berakibat pada terbukanya berbagai pilihan dan kesempatan mengembangkan diri di masa depan. Dengan demikian, pendidikan mempunyai peranan amat sentral dalam mendorong individu dan masyarakat untuk mencapai kemajuan pada semua aspek kehidupan (Mutammam, 2007:189).

Dewasa ini, adanya kemajuan ilmu pengetahuan dan teknologi (IPTEK) yang sangat pesat, serta adanya tuntutan kebutuhan hidup yang relatif tinggi telah membawa impact pada dinamika perubahan yang sangat drastis terhadap seluruh aspek dan sendi kehidupan manusia. Akibatnya terjadi lompatan-lompatan dalam perkembangan peradaban manusia di muka bumi ini.

Impact yang menyertai kemajuan IPTEK dan kebutuhan tiap manusia tersebut di satu sisi telah membawa manusia pada kondisi dan situasi yang diuntungkan, namun ternyata di fihak lain telah membawa negative impact terhadap mindset dan life style manusia itu sendiri, sehingga tidak hanya bersinggungan dengan permasalahan tataran pribadi tiap individu, melainkan merambah pada sebuah problematika bangsa yang cukup serius dalam berbagai aspek kehidupan. Berbagai masalah yang dapat diugkapkan di sini misalnya masih merajalelanya kenakalan remaja atau peserta didik, illegal loging, maraknya kejahatan, aborsi, narkoba, amoral oleh pendidik ataupun pejabat, anarkhisme, radikalisme, bahkan "budaya" korupsi yang sampai sekarang belum bisa diminimalisir secara baik (Maksum, 2009:199).

Berbagai problem bangsa tersebut tentunya tidak begitu saja bisa hilang secara sendirinya, atau hanya merupakan tanggung jawab aparat pemerintah dan elemen tertentu, namun harus dipikul secara bersama oleh seluruh elemen bangsa ini tak terkecuali Islam. Untuk mengatasai permaslahan-permasalahan tersebut diperlukan pendekatan yang benarbenar efektif dan efsien agar memperoleh hasil dan solusi yang tepat. Islam memberikan sumbangsihnya yang konstruktif melalui perspektif pendidikannya. Pendidikan dengan seluruh sistem yang mendukungnya akan memberikan andil besar dalam membangun karakter dan kepribadian individu, masyarakat, bahkan bangsa yang lebih mencerahkan manusia dan peradaban yang gemilang. (Maksum, 2009:200)

Dari berbagai penjelasan mengenai arti pentingnya pendidikan dan problematika yang mewarnainya, kajian ini sangat relevan dengan hal tersebut, maka penulis tertarik untuk melakukan kajian dengan mengangkat judul "Implementasi Prinsip-Prinsip Pendidikan dalam Islam". 


\section{METODE PENELITIAN}

Kajian ini menggunakan metode deskriptif kualitatif melalui pendekatan kajian literatur terhadap tafsir tentang ayat-ayat yang berkaian dengan pendidikan. dalam Alquran, serta membaca berbagai buku, jurnal, dan terbitan-terbitan lain yang berkaitan dengan topik penelitian, yang bertujuan untuk memberikan gambaran secara sistematis tentang penerapan prinsipprinsp pendidikan sesuai dengan Alquran.

\section{HASIL DAN PEMBAHASAN}

\section{Prinsip Pendidikan}

Prinsip (akar katanya: principia) diartikan sebagai permulaan yang dengan cara tertentu melahirkan hal-hal lain, yang keberadaannya tergantung dari pemula itu. (an-Nahlawi, 1989:15) Dalam Kamus Besar Bahasa Indonesia, kata "prinsip" berarti asas atau dasar yaitu: kebenaran yang menjadi pokok dasar berpikir, bertindak, dan sebagainya. Jadi, apabila dikaitkan dengan pendidikan, maka prinsip pendidikan dapat diartikan sebagai kebenaran yang universal sifatnya dan menjadi dasar dalam merumuskan perangkat pendidikan. Prinsip pendidikan diambil dari dasar pendidikan, baik berupa agama atau ideologi yang dianut. Prinsip pendidikan Islam ditegakkan di atas dasar yang sama dan berpangkal dari pandangan Islam secara filosofis terhadap jagad raya, manusia, masyarakat,ilmu pengetahuan dan akhlak. Pandangan Islam terhadap masalah-masalah tersebut, melahirkan berbagai prinsip dalam pendidikan Islam. $\begin{array}{ccc}\text { Dalam } & \text { Kamus Besar } & \text { Bahasa } \\ \text { Indonesia } & \text { disebutkan } & \text { bahwa }\end{array}$ pendidikan ialah: "Proses pengubahan sikap dan tata laku seseorang atau kelompok orang dalam usaha mendewasakan manusia melalui upaya pengajaran dan pelatihan". Ki Hajar Dewantara menyatakan: "Pendidikan umum nya berarti daya upaya untuk memajukan budi pekerti (kekuatan bathin), pikiran (intellect) dan jasmani anak- anak selaras dengan alam dan masyarakatnya" (Dewantara, 1967:42). Muhammad Natsir dalam tulisannya Ideologi Islam, menulis: "Yang dinamakan pendididikan, ialah satu pimpinan jasmani dan rohani yang menuju kepada kesempurnaan dan kelengkapan arti kemanusiaan dengan arti sesungguhnya" (Natsir, 1954:87). Ahmad D. Marimba mengajukan definisi pendidikan sebagai berikut: "Pendidikan adalah bimbingan atau pimpinan secara sadar oleh pendidik terhadap perkembangan jasmani dan rohani orang yang terdidik menuju terbentuknya kepribadian yang utama" (Marimba, 1980:19).

Hasil rumusan Seminar Pendidikan Islam se-Indonesia pada tahun 1960, memberikan pengertian pendidikan Islam sebagai "bimbingan terhadap pertumbuhan rohani dan jasmani menurut ajaran Islam dengan hikmah mengarahkan, mengajarkan, melatih, mengasuh, dan mengawasi berlakunya semua ajaran Islam" (Arifin, 2010:15).

Pendidikan sebenarnya dapat ditinjau dari dua segi. Pertama dari sudut pandang masyarakat, dan kedua dari segi pandangan individu. Dari segi pandangan masyarakat, pendidikan berarti pewarisan kebudayaan dari generasi tua kepada generasi muda, 
agar hidup masyarakat tetap berkelanjutan. Atau dengan kata lain, masyarakat mempunyai nilai-nilai budaya yang ingin disalurkan dari generasi ke generasi agar identitas masyarakat tersebut tetap terpelihara. Nilai-nilai ini bermacam-macam. Ada yang bersifat intelektual, seni, politik, ekonomi dan lain-lain lagi.

Dilihat dengan kaca mata individu, pendidikan berarti pengembangan potensi-potensi yang terpendam dan tersembunyi. Manusia mempunyai berbagai bakat dan kemampuan yang kalau pandai kita mempergunakannya bisa berubah menjadi emas dan intan, bisa menjadi kekayaan yang berlimpah-limpah. Kemampuan intelektual saja beraneka ragam. Kemampuan bahasa, menghitung, mengingat, berfikir, dayacipta dan lain-lain.

Dari berbagai pengertian di atas, dapat diambil kesimpulan bahwa prinsip pendidikan adalah: kebenaran yang universal sifatnya dan menjadi dasar dalam usaha mengubah tingkah laku individu dalam kehidupan pribadinya atau kehidupan kemasyarakatannya dan kehidupan dalam alam sekitarnya melalui proses kependidikan, yang berorientasi pembentukan pribadi anak didik yang beradab, taat hukum, menjunjung tinggi etika atau sopan santun.

\section{Prinsip-Prinsip Pendidikan Dalam Alquran}

a. Beorientasi pada Islam

Pendidikan Islam sejak awal merupakan salah satu usaha untuk menumbuhkan dan memantapkan kecendrungan tauhid yang telah menjadi fitrah manusia. Agama menjadi petunjuk dan penuntun ke arah itu. Oleh karena itu, pendidikan Islam selalu menyelenggrakan pendidikan agama. Namun, agama di sini lebih kepada fungsinya sebagai sumber moral nilai. Sesuai dengan ajaran Islam pula, pendidikan Islam bukan hanya mengajarkan ilmu-ilmu sebagai materi, atau keterampilan sebagai kegiatan jasmani semata, melainkan selalu mengaitkan semuanya itu dengan kerangka praktik ('amaliyyah) yang bermuatan nilai dan moral. Jadi, pengajaran agama dalam Islam tidak selalu dalam pengertian (ilmu agama) formal, tetapi dalam pengertian esensinya yang bisa saja berada dalam ilmu-ilmu lain yang sering dikategorikan secara tidak proporsional sebagai ilmu sekuler.

\section{b. Prinsip Shumuliyyah (universal)}

Prinsip ini memandang pendidikan sebagai sesuatu yang utuh, menyangkut seluruh aspek kehidupan manusia, yang meliputi agama, masyarakat serta adanya wujud jagad raya, ibadah, akhlak, dan muamalah. Prinsip ini menimbulkan formulasi tujuan pendidikan secara terbuka, serta mengembangkan dan mendidik segala aspek kepribadian manusia, meningkatkan kualitas kehidupan ekonomi, sosial, budaya dan politik untuk menyelesaikan semua masalah dalam menghadapi tuntutan masa depan.

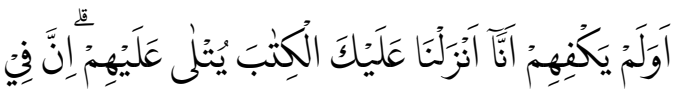

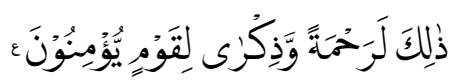

"Dan apakah tidak cukup bagi mereka bahwasanya Kami telah menurunkan kepadamu Al Kitab (Alquran) sedang dia dibacakan 
kepada mereka? Sesungguhnya dalam (Alquran) itu terdapat rahmat yang besar dan pelajaran bagi orang-orang yang beriman." (QS. al'Ankabūt/29: 51)

Salah satu diantara problemproblem yang mewarnai dunia pendidikan Islam adalah terjadi dikotomi dalam beberapa aspek yaitu; antara Ilmu Agama dengan Ilmu Umum, antara Wahyu dengan Akal serta antara Wahyu dengan Alam. Pandangan yang dikotomis tersebut pada giliran selanjutnya dikembangkan dalam melihat dan memandang aspek kehidupan dunia dan akhirat, kehidupan jasmani dan rohani sehingga pendidikan Islam hanya diletakkan pada aspek kehidupan akhirat saja atau kehidupan rohani saja.

Munculnya masalah dikotomi dengan segala perdebatannya telah berlangsung sejak lama. Pada periode pertengahan, lembaga pendidikan Islam (terutama madrasah sebagai pendidikan tinggi) tidak pernah menjadi universitas yang difungsikan sematamata untuk mengembangkan tradisi penyelidikan bebas berdasarkan nalar. la banyak diabdikan kepada ilmu-ilmu agama dengan penekanan pada fiqh, tafsir dan hadist. Sementara ilmu-ilmu non agama (keduniaan), terutama ilmuilmu alam dan eksakta sebagai akar pengembangan sains dan teknologi, sejak awal perkembangan Madrasah dan al-Jami'ah sudah berada dalam posisi marginal.

Dalam ayat Alquran yang pertama kali diturunkan, Allah memerintahkan agar mansuia untuk membaca yaitu dalam QS al-'Alaq ayat 1-5. Dan ditempat lain ditemukan ayat yang menafsirkan perintah membaca tersebut, seperti dalam Firman Allah:

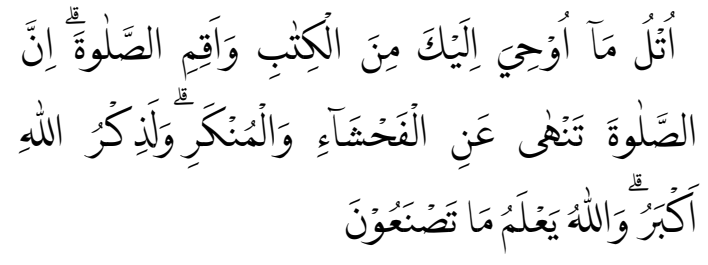

"Bacalah apa yang telah diwahyukan kepadamu, Yaitu Al kitab (Alquran) dan dirikanlah salat. Sesungguhnya salat itu mencegah dari (perbuatan- perbuatan) keji dan mungkar. dan Sesungguhnya mengingat Allah (salat) adalah lebih besar (keutamaannya dari ibadatibadat yang lain). dan Allah mengetahui apa yang kamu kerjakan." (QS. al-Ankabut/29: 45)

Islam tidak membedakan antara ilmu-ilmu agama dan ilmu umum (keduniaan), dan/atau tidak berpandangan dikotomis terhadap ilmu pengetahuan. Namun demikian dalam realitas sejarahnya justru supremasi lebih diberikan pada ilmuilmu agama sebagai jalan tol untuk menuju Tuhan. Untuk itu dikhotomi dalam pendidikan Islam perlu dihapuskan sebab dengan menerima prinsip ini, maka pendidikan Islam hanya akan melahirkan manusiamanusia Muslim yang terpecah kepribadiannya, di masjid atau di langgar mereka bersikap alim, sementara di pasar, di pabrik dan di masyarakat luas mereka tampil sebagai orang asing yang tidak punya orientasi moral, kepedulian social, kasih sayang, kejujuran dan tanggung jawab. Oleh karena, itu ajaran Islam tidak mengenal pemisahan antara ilmu agama dan ilmu umum. Dalam arti, tidak ada pandangan dikotomis mengenai ilmu pengetahuan. Kedua ilmu tersebut harus dimiliki secara integral, agar fungsi khalifah dan ' abid, tadi terlaksana dengan maksimal. (Zainudin, t.t.:46) 


\section{c. Prinsip Keseimbangan}

Manusia hidup di bumi berfungsi sebagai khalîfah dan âbid, hal tersebut merupakan satu kesatuan yang tidak bisa dipisahkan, melainkan harus dicapai secara simultan. Oleh karena itu, pendidikan harus berusaha menyeimbangkan dan menyelaraskan kehidupan baik material maupun spiritual, individu maupun sosial, pengetahuan dan moral, intelektual dan emosional, yang terintegrasi dalam kerangka yang utuh, sehingga tercapai keseimbangan hidup antara dunia dan akhirat.

Allah berfirman:

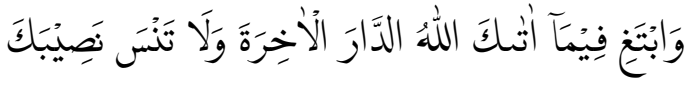

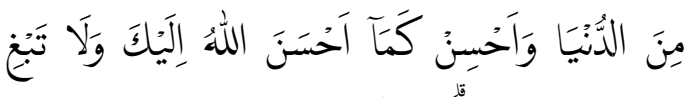

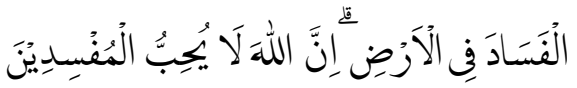

"Dan carilah pada apa yang telah dianugerahkan Allah kepadamu (kebahagiaan) negeri akhirat, dan janganlah kamu melupakan bahagianmu dari (kenikmatan) duniawi dan berbuat baiklah (kepada orang lain) sebagaimana Allah telah berbuat baik, kepadamu, dan janganlah kamu berbuat kerusakan di (muka) bumi. Sesungguhnya Allah tidak menyukai orang-orang yang berbuat kerusakan". (QS. al-Qașaș/28: 77)

Allah juga telah menciptakan segala sesuatu di dunia ini dalam keadaan seimbang. Sebagaimana firman Allah:

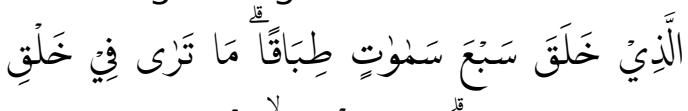

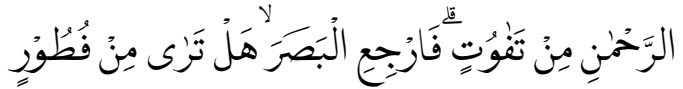

"Yang telah menciptakan tujuh langit berlapis-lapis. Kamu sekalikali tidak melihat pada ciptaan
Tuhan Yang Maha Pemurah sesuatu yang tidak seimbang. Maka lihatlah berulang-ulang, adakah kamu lihat sesuatu yang tidak seimbang?" (QS. al-Mulk/67: 3)

Selain keseimbangan antara urusan dunia dan akhirat, Alquran juga mengajarkan keseimbangan antara kepentingan jasmani dan rohani. Suatu kenyataan yang tidak bisa diingkari bahawa manusia lahir ke dunia ini dibekali dengan kecenderungan pembawaan daya imaginasi dan akal yang berbeda. Allah Swt berfirman:

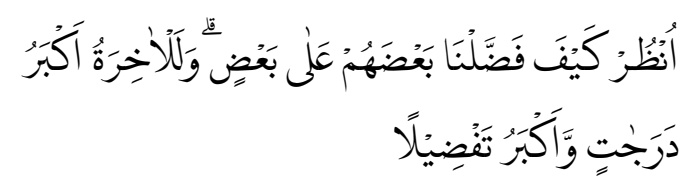

"Perhatikanlah bagaimana Kami lebihkan sebagian dari mereka atas sebagian (yang lain). Dan pasti kehidupan akhirat lebih tinggi tingkatnya dan lebih besar keutamaannya". (QS. al-Isrā'/17: 21)

Pendidikan Islam memperhatikan perbedaan fisik dan psikis seorang sebagai salah satu faktor yang harus dipertimbangkan dalam menyusun program kependidikan. Prinsip ini didasarkan atas pandangan filosofis bahwa tujuan pendidikan pada hakekatnya adalah untuk menumbuhkembangkan aspek fisik dan psikis anak. Alquran juga mengajarkan kesetaraan dalam pendidikan. Dalam surah 'Abasa dijelaskan:

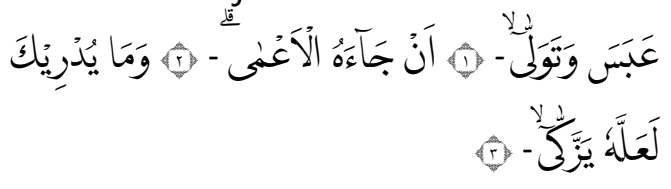

"Dia (Muhammad) bermuka masam dan berpaling, karena telah datang seorang buta kepadanya. Tahukah kamu barangkali ia ingin 
membersihkan dirinya (dari dosa)". (QS. 'Abasa /80: 1-3)

Dari ayat-ayat tersebut dapat diambil hikmah bahwa setiap insan berhak memperoleh pendidikan, tanpa mengenal ras, suku bangsa, agama maupun kondisi pribadi/fisik dan perekonomiannya. Sebagai seorang pendidik harus bijak dalam menghadapi anak didiknya dan tidak membedabedakan hanya karena fisik yang tidak sempurna. Misal tingkatkan pula pelayanan pendidikan pada peserta didik yang difabel.

\section{d. Menjaga Perbedaan Individu}

Alquran mengajarkan untuk menjaga perbedaan-perbedaan individu dalam pendidikan. Perbedaan yang dimiliki manusia melahirkan perbedaan tingkah laku, karena setiap orang akan berbuat sesuai dengan keadaannya masing-masing.

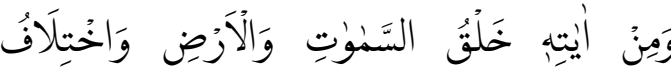

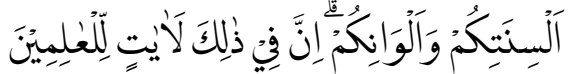

"Dan di antara tanda-tanda kekuasaan-Nya ialah menciptakan langit dan bumi dan berlain-lainan bahasamu dan warna kulitmu. Sesungguhnya pada yang demikan itu benar-benar terdapat tandatanda bagi orang-orang yang mengetahui." (QS. Al-Rūm/30: 22)

\section{e. Pendidikan Seumur Hidup}

Pendidikan seumur hidup adalah sebuah sistem pendidikan yang menerangkan keseluruhan peristiwa kegiatan belajar mengajar yang berlangsung dalam keseluruhan kehidupan manusia (Basuki dan Miftahul Ulum, 2017:154). Jauh sebelum
PBB (Perserikatan Bangsa-bangsa) pada tahun 1970-an memprakarsai "Pendidikan seumur hidup-PSH"/ "Life long integrated education", Rasulullah Saw. pada abad ketujuh telah bersabda

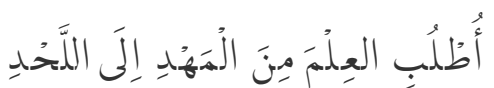

"Tuntutlah ilmu mulai dari buaian sampai liang lahat (meninggal dunia).

Hal ini dikarenakan ilmu Allah tidak akan pernah ada habisnya untuk dipelajari. Allah SWT berfirman tentang itu bahwa seandainya semua pohon yang kita temukan di planet digunakan sebagai pena dan air yang di samudra digunakan sebagai tintanya ditambah sebanyak tujuh kali lipat maka ilmu itu tidak akan habis ditulis. Asas pendidikan seumur hidup bertitik tolak atas keyakinan bahwa proses pendidikan dapat berlangsung selama manusia hidup, baik di dalam maupun di luar sekolah. Adanya konsep pendidikan seumur hidup mendorong kita supaya menyadari bahwa :

1) Proses pendidikan berlangsung seumur hidup (kandunganmeninggal), yang berarti memberi tanggung jawab pedagogis / psikologis kepada orang tua, lebihlebih kepada ibu yang mengandung untuk membina kandungannya secara psiko-fesis yang ideal.

2) Tidak ada batas waktu untuk belajar. Tidak ada kata "terlambat" atau "terlalu dini" untuk belajar, berarti pula tidak ada konsep "terlalu tua" untuk belajar.

3) Pendidikan adalah kehidupan itu sendiri. (Tim Dosen FIP-IKIP Malang: 123-126). 
Islam tidak saja mencukupkan pada anjuran supaya belajar saja, tetapi juga supaya seseorang itu terus menerus melakukan pembahasan, penelitian dan pendalaman. Sebagaimana Nabi Saw. bersabda:

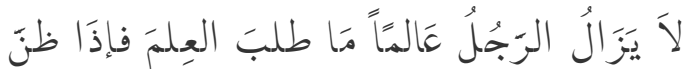

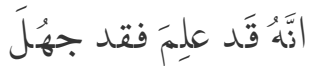

"Tidaklah henti-hentinya seseorang itu dapat dianggap orang berilmu ('alim) selama ia masih terus belajar ilmu. Apabila ia menyangka bahwa sesungguhnya ia sudah serba tahu, maka sungguh ia seseorang yang jahil".

Sedangkan landasan pendidikan seumur hidup yang terdapat dalam alquran diantaranya terdapat dalam Q.S. Āli ‘Imrān/3:79

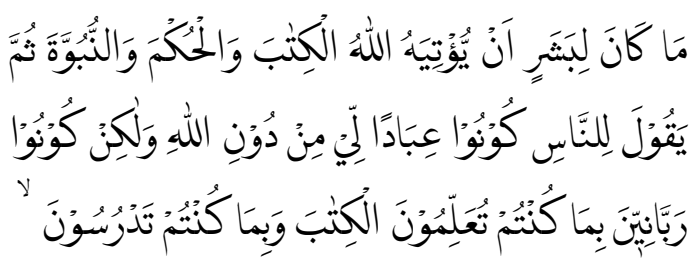

"Tidak wajar bagi seseorang manusia yang Allah berikan kepadanya Al Kitab, hikmah dan kenabian, lalu dia berkata kepada manusia: "Hendaklah kamu menjadi penyembah-penyembahku bukan penyembah Allah". Akan tetapi (dia berkata): "Hendaklah kamu menjadi orang-orang rabbani, karena kamu selalu mengajarkan Al Kitab dan disebabkan kamu tetap mempelajarinya". $\quad$ (Q.S. $\quad \overline{A l i}$ 'Imrān:79)

\section{f. Prinsip Bagian dari Proses Rubūbiyyah}

Alquran menggambarkan bahwa Allah adalah Al-Khāliq, dan Rabb AlAmin (pemelihara semesta alam). Dalam proses penciptaan alam semesta termasuk manusia. Allah menampakan proses yang memperlihatkan konsistensi dan keteraturan. Hal demikian kemudian dikenal sebagai aturan-aturan yang diterpakan Allah atau disebut Sunnatullah. Sebagaiman Al-Kailani yang dikutip oleh Bukhari Umar dalam bukunya menjelaskan, bahwa peranan manusia dalam pendidikan secara teologis dimungkinkan karena posisinya sebagai makhluk, ciptaan Allah, yang paling sempurna dan dijadikan sebagai khalifat Allah fi al-ard.

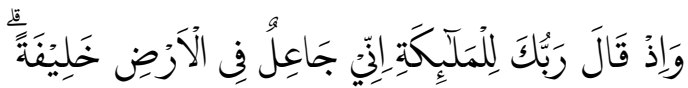

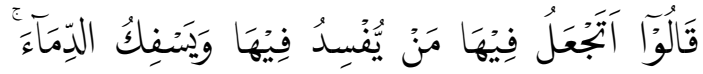

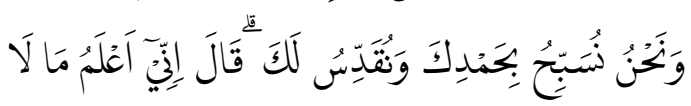
تَعْلَمَونَنَ

"Ingatlah ketika Tuhanmu berfirman kepada para Malaikat: "Sesungguhnya Aku hendak menjadikan seorang khalifah di muka bumi". Mereka berkata: "Mengapa Engkau hendak menjadikan (khalifah) di bumi itu orang yang akan membuat kerusakan padanya dan menumpahkan darah, padahal kami senantiasa bertasbih dengan memuji Engkau dan mensucikan Engkau?" Tuhan berfirman: "Sesungguhnya Aku mengetahui apa yang tidak kamu ketahui".

Sebagai khalifah, manusia juga mengemban fungsi rubbübiyyah Allah terhadap alam semesta termasuk diri manusia sendiri. Dengan perimbangan tersebut dapat dikatakan bahwa karakter hakiki pendidikan Isam pada intinya terletak pada fungsi rubūbiyyah Allah secara praktis dikuasakan atau 
diwakilkan kepada manusia. Dengakn kata lain, pendidikan Islam tidak lain adalah keseluruhan proses dan fungsi rubübiyyah Allah terhadap manusia, sejak dari proses penciptaan samspai dewasa dan sempurna.

\section{Tauhid Sebagai Prinsip Pendidikan}

a. Pengertian Tauhid

Kata tauhid berasal dari bahasa Arab, mașdar dari wahhada yang berarti mengesakan (Classe, 1989:400). Kata wahhada sendiri bentukan dari kata wahada atau wahuda dengan arti (infarada). Dengan demikian, kata tauhid bermakna mengesakan atau menyatukan. Kata tauhid telah menjadi kata yang baku dalam bahasa Indonesia yang berarti keesaan Allah; mentauhidkan berarti mangakui keesaan Allah atau mengesakannya. Tauhid ialah mengesakan Allah Swt. dalam beribadah kepadaNya. Dan itulah agama semua para rasul yang diutus oleh Allah kepada seluruh hambaNya (al-Maghribi, 2004:136). Kata tauhid, yang dikehendaki di sini, tidak lain dari Tauhid Allah, yang berarti mengesakan Allah, atau dengan kata lain menyatakan bahwa Allah (Tuhan) itu esa, satu, atau tunggal.

Menegakkan akidah tauhid adalah ajaran yang paling kuat mendapat tekanan dalam Islam. Ajaran bahwa tidak ada Tuhan selain Allah, la ilaha illa Allah atau tidak ada yang patut ditaati dan disembah kecuali Allah adalah paling esensial dan sentral dalam Alquran dan hadis Nabi. Pada dasarnya, inti pokok ajaran Alquran adalah tauhid. Nabi Muhammad Saw. diutus Allah kepada umat. Menurut perspektif Alquran, tauhid merupakan akar utama yang harus memberikan energi kepada pokok, dahan, dan daun kehidupan. Atau ia merupakan hulu yang harus menentukan gerak dan kualitas air sebuah sungai kehidupan. Semua aktivitas kehidupan mestilah berangkat dari tauhid tersebut, termasuk kegiatan dan penyelenggaraan pendidikan.

\section{b. Tauhid sebagai Prinsip Pendidikan}

Pendidikan bermula dari prinsip Tauhid. Hal inilah yang menjadi dasar pijakan dalam pandangan terhadap pendidikan. Prinsip Tauhid mencakup konsep filosofis maupun metodologis yang terstruktur dan koheren terhadap pemahaman kita terhadap dunia dan seluruh aspek kehidupan. Tauhid mengajarkan kita untuk menghimpun pandangan yang holistik, terpadu, dan komprehensif terhadap pendidikan. Lebih dari itu, prinsip Tauhid menuntut para pendidik mempunyai pandangan yang menyeluruh dan tujuan sejati terhadap pendidikan dan kehidupan itu sendiri. Oleh karena itu, konsep Tauhid harus menjadi landasan tentang bagaimana kita mendidik anak, termasuk (1) apa yang diajarkan (isi), (2) bagaimana kita mengorganisir dan apa yang harus diajarkan, (3) bagaimana kita mengajarkannya. Akhirnya, Tauhid haruslah membentuk fondasi pemikiran, metodologi, dan praktik pendidikan kita. (Zainudin, 2008:109).

Pendidikan terdiri atas beberapa komponen, yaitu murid, guru, dan kurikulum. Nilai tauhid mestinya tercermin pada setiap komponen itu. Nilai tauhid mesti mewarnai pribadi siswa dan guru serta intreraksi atau komunikasi antara keduanya. Guru mestinya tampil sebagai pribadi yang bertauhid, yang tercermin dalam prilaku, tutur sapa, pikiran, dan rasa. 
Semuanya mesti diwarnai oleh tauhid, seperti yang terlihat pada pribadi para nabi mulai dari Adam As samapai Muhammad Saw. Demikian pula siswa; mereka ini mestinya dilihat sebagai komunitas pencari nilai-nilai tauhid. Maka semua aktivitas belajar dan interaksi antara guru dan murid tidak boleh bertentangan dengan nuansa tauhid itu.

Dan komponen pendidikan yang juga amat penting dibangun atas prinsip tauhid adalah kurikulum. Kurikulum yang antara lain mencakupi materi, metode, dan alokasi waktu hendaknya dibangun atas pertimbangan ajaran tauhid. Materi pelajaran, misalnya, ditetapkan dengan berlandaskan pada Alquran dan Sunnah serta berorientasi kepada penanaman kesadaran diri sebagai makhluk Allah, bukan semata-mata penanaman ilmu. Ilmu mestinya dilihat sebagai sarana yang menjembatani peserta didik untuk mencapai ketauhidan yang hakiki, yaitu penyerahan diri sepenuhnya kepada Allah. Bangunan kurikulum seperti ini mencakupi semua bidang kajian yang disajikan kepada siswa; tidak ada materi pelajaran, bidang kajian apapun, yang tidak berlandaskan ketauhidan.

Masalah pendidikan tauhid atau keimanan ini telah diprioritaskan dalam pendidikan Islam untuk upaya pembentukan kepribadian muslim, sebagaimana diilustrasikan berturutturut dalam QS. Luqmān ayat 12-19. Dalam ayat tersebut terkandung tiga ajaran pokok Islam, yaitu masalah keimanan atau ketauhidan, masalah akhlak dan masalah peribadatan. Manusia harus memiliki jiwa tauhid sehingga ia menjadi manusia yang beriman dengan sebenar-benarnya. Salah satu usaha untuk menanamkan dan menguatkan jiwa tauhid adalah melalui pendidikan. Namun, pendidikan itu pun harus memiliki prinsip tauhid. Pendidikan dengan tauhid sebagai prinsip utama akan memberi nilai tambah bagi manusia dan menumbuhkan kepercayaan pada dirinya serta mempunyai pegangan hidup yang benar. Bagi orang yang tidak menjadikan tauhid sebagai dasar pendidikan maka ia seakan kehilangan tempat berpijak. Keimanan akan menjadikan si pemiliknya mampu mengendalikan hawa nafsu, dan mengembalikan segala persoalan kepada ketentuan Allah dan Rasul-Nya (Susanto:110).

Al-Ghazali mengatakan bahwa, ajaran akidah tauhid seharusnya diajarkan sedini mungkin kepada anakanak, supaya dihafalkan dengan baik, baru kemudiann berangsur-angsur difahami maknanya. Setelah dipahami dan dimengerti, akidah tauhid tersebut diyakini dan dipercayai (al-Ghazali, t.th:93).

Pembinaan keimanan ini merupakan hal yang mendasar dan fundamental dalam pendidikan Islam, karena dari keimanan inilah berpangkalnya segala peribadatan. Makin tebal iman seseorang makin baik ibadahnya, karena peribadatan merupakan manifestasi dari keimanan. Ibadah yang menjadi manifestasi iman seseorang itu bertujuan untuk mendekatkan diri kepada Allah, agar dengan demikian roh manusia selalu diingatkan pada halhal yang bersih lagi suci, sehingga akhirnya rasa kesucian seseorang menjadi kuat dan tajam. Roh suci membawa kepada akhlak yang baik (Nasution, 1991:71). 


\section{Implikasi Tauhid dalam Pembentukan Kepribadian Muslim}

Tauhid mempunyai beberapa implikasi dalam pembentukan kepribadian muslim, antara lain:

a. Tauhid membentuk kepribadian utuh

Pengaruh tauhid dalam kepribadian seseorang adalah terhindarnya dari keterbelahan kepribadian. Bagi orang yang bertauhid, orientasi jiwa dan raganya hanya diperuntukkan pada Allah semata, sehingga kepribadiannya utuh. Keutuhan jiwa itulah yang menjadikan seorang yang bertauhid menjadi tenang dalam menghadapi kehidupan ini. Namun, kepribadian orang yang syirik, yang menjadikan Allah mempunyai serikat, mengalami keterbelahan.

Allah membuat perumpamaan bagi orang musyrik dan orang yang bertauhid. Orang musyrik itu diumpamakan seorang budak yang dimiliki oleh beberapa manusia yang berserikat yang dalam perselisihan. Budak tersebut pastilah akan terpecah pengabdiannya kepada beberapa tuannya sehingga kepribadiannya akan terbelah. Sama halnya seorang yang musyrik, yang menyembah beberapa Tuhan, pastilah kepribadiannya menjadi pecah. Dalam pada itu, seorang yang bertauhid diumpamakan seperti seorang budak yang hanya dimiliki oleh seorang saja, tidak dimiliki oleh banyak orang. Budak tersebut dapat mengabdikan dirinya sepenuh hati kepada tuannya (al-Ṭabatabā' $\bar{i}$, t.t:258).

Sigmund Freud seorang psikolog materialis dan ateis dan G. Jung menerima data statistik yang menunjukkan bahwa secara psikologis masyarakat yang beriman kepada Allah paling terselamatkan kepribadiannya ketimbang yang lain. Hal ini disebabkan adanya keutuhan dan kesatuan kepribadiannya. (Muthahhari, 1992: 37). Melihat berbagai pendapat yang dikemukakan oleh para ahli di atas dan apa yang diperoleh dari Alquran, maka jelaslah bahwa tauhid yang terutama berkaitan dengan keimanan kepada Allah Swt. Itu menjadikan seorang terhindar dari keterbelahan kepribadian. Dengan demikian tauhid dapat membentuk kepribadian seseorang menjadi utuh, tidak terpecah, karena tidak terjadi konflik dalam jiwa seorang individu yang punya keimanan terhadap Tuhan Yang Satu. Kenyataan pengaruh iman terhadap keutuhan kepribadian seseorang ini juga diakui oleh pakar psikologi, seperti James. C. G. Jung dan Sigmund Freud.

b. Tauhid membentuk kepribadian terbuka

Kepribadian yang terbuka adalah kepribadian yang memungkinkan menerima kebenaran dari orang lain. Kepribadian terbuka itu berarti kepribadian yang tidak hanya menerima kebenaran yang berasal dari dirinya. Huston mengatakan bahwa, keengganan manusia untuk menerima kebenaran ialah antara lain karena sikap menutup diri yang timbul dari keengganan untuk mengetahui kebenaran yang justru lebih tinggi nilainya. Halangan orang untuk menerima kebenaran ialah keangkuhannya sendiri dan juga belenggu yang diciptakan oleh dirinya sendiri. Belenggu itu ialah hawa nafsu yang berarti keinginan diri sendiri. (Nurcholis Madjid, 1992, hal. 81) Hawa nafsu itulah yang menghalangi manusia menerima kebenaran dan menjadikan 
kepribadian manusia tertutup. Manusia yang memutlakkan diri, pandangan, dan pikirannya, menurut Alquran disebut telah menuhankan hawa nafsunya. Allah berfirman dalam QS. alJāthiyāt/45: 23 yang artinya sebagai berikut:

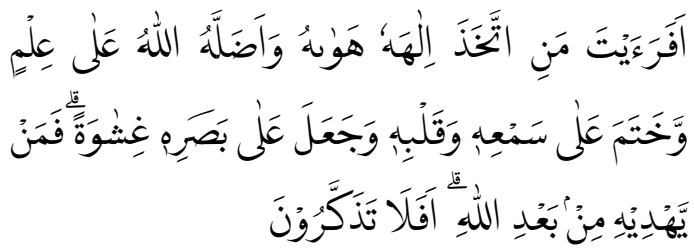

"Maka pernahkah kamu melihat orang yang menjadikan hawa nafsunya sebagai Tuhannya dan Allah membiarkannya berdasarkan ilmu-Nya[1384] dan Allah Telah mengunci mati pendengaran dan hatinya dan meletakkan tutupan atas penglihatannya? Maka siapakah yang akan memberinya petunjuk sesudah Allah (membiarkannya sesat). Maka Mengapa kamu tidak mengambil pelajaran?"

Orang yang menuhankan hawa nafsunya itu akan mudah terseret kepada sikap-sikap tertutup dan fanatik, yang mudah bereaksi negatif pula terhadap sesuatu yang datang dari luar, tanpa sempat meneliti kemungkian kebenaran dalam apa yang datang dari luar. Ketika orang mengikuti hawa nafsunya, maka perbuatannya menjadi bertentangan dengan logikanya, dengan akal sehat dan dengan pertimbangan yang matang. Oleh karena itu, Alquran menyebutkan faktor penting kesalahan manusia adalah dengan menuhankan hawa nafsunya itu. Manusia yang mengikuti atau manuhankan hawa nafsunya itu berarti manganggap hanya dirinya yang benar. (Muthahhari, 1992:52)
Orang yang memperoleh petunjuk Allah ialah orang yang mendengarkan perkataan kemudian memahami perkataan tersebut dan mengambil yang terabik di antaranya. Menurut alRāzi dan al-Ṭabari, kata "al-qawl" itu meliputi sabda- sabda Nabi dan firman Tuhan, serta pendapat sesama manusia. Nilai-nilai yang terkandung dalam ayatayat Alquran tersebut adalah nilai-nilai keterbukaan. Dengan demikian sikap keterbukaan adalah bagian dari iman. Orang yang bertauhid yang hanya memutlakkan Allah saja tentulah manusia yang terbuka. (Madjid, 1994:10)

\section{c. Tauhid membentuk kepribadian berani}

Muhammad Iqbal berpendapat bahwa, keberanian dapat dipupuk dan dijadikan salah satu pertanda dari watak atau kepribadian dengan jalan menjadikan tauhid sebagai dasar kerja yang melandasi segala tingkah laku seseorang. Penerapan tauhid dalam segala kegiatan seseorang sehari-hari, menurut pandangan Iqbal, mengandung arti penolakan mentahmentah segala bentuk dan macam kekuatan kecuali taat kepada Allah. Dengan tauhid seseorang mampu menghadapi segala tantangan dengan jantan kekuatan yang akan membelenggu kebebasan berkembang dan berfikir.

Manusia yang bertauhid tidak menampilkan diri sebagai yang paling benar, sebab dia menyadari yang mutlak benar hanyalah Allah Swt. Selain Dia adalah nisba yang berarti mengandung kemungkinan salah. Berdasar pandangan tersebut, maka manusia yang bertauhid mempunyai pandangan terbuka, menerima 
kemungkinan-kemungkinan kebenaran dari selain dirinya. Dengan demikian, manusia yang bertauhid adalah manusia yang mempunyai kepribadian yang terbuka. Mereka terhindar dari kepribadian yang berdasarkan anggapan-anggapan keliru karena berdasar hawa nafsu. Kepribadian terbuka yang didasarkan atas kepercayaan tauhid tersebut memungkinkan seseorang menjadi individu yang selalu mendengarkan pendapat orag lain, kemudian mencoba memahami dengan kritis. Berkaitan dengan sikap terbuka ini Allah berfirman dalam QS. al-Zumar/39: 1718 yang berbunyi sebagai berikut:

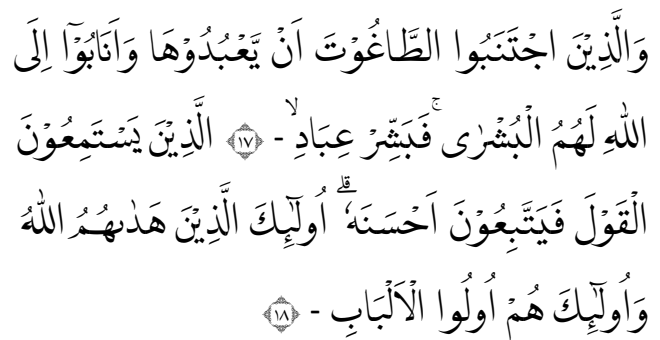

"Yang mendengarkan Perkataan lalu mengikuti apa yang paling baik di antaranya. mereka Itulah orangorang yang telah diberi Allah petunjuk dan mereka Itulah orangorang yang mempunyai akal. Apakah (kamu hendak merobah nasib) orang-orang yang telah pasti ketentuan azab atasnya? Apakah kamu akan menyelamatkan orang yang berada dalam api neraka?" (QS. al-Zumar/39: 18-19)

Maksudnya ialah mereka yang mendengarkan ajaran-ajaran Alquran dan ajaran-ajaran yang lain, tetapi yang diikutinya ialah ajaranajaran Alquran karena ia adalah yang paling baik.

Sesungguhnya orang yang bertauhid itu selalu mempunyai keyakinan bahwa Allah Swt. Selalu berada di dekatnya, sehingga dia tidak mempunyai rasa takut sedikitpun, sebagaiman firman Allah dalam QS. alTawbah/9: 40. Selain itu, Allah juga menyatakan bahwa orang yang beriman kepada-Nya dan kemudian dia tetap dalam akidah tauhidnya itu, maka Allah menjamin orang itu tidak akan merasa takut dan tidak akan susah, sebagaimana firman-Nya pada QS. alAḥāaf/46: 13 yang berbunyi sebagai berikut:

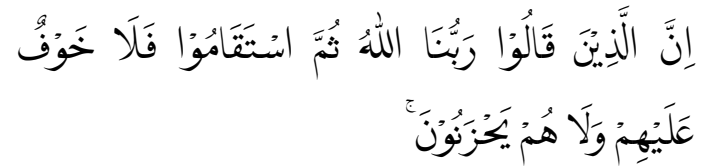

"Sesungguhnya orang-orang yang mengatakan: "Tuhan Kami ialah Allah", kemudian mereka tetap istiqamah. Maka tidak ada kekhawatiran terhadap mereka dan mereka tiada (pula) berduka cita". (QS. al-Ahqāa /46: 13)

\section{d. Tauhid Membentuk Kepribadian Bebas}

Tauhid, sebagaimana diketahui, berarti suatu keyakinan bahwa Allah Yang Maha Esa adalah mutlak, sedangkan selain-Nya adalah nisbi. Karena itu, hubungan manusia dengan Allah tidak setara dibandingkan hubungannya dengan sesama makhluk. Tauhid yang terumuskan dengan kalimat "Là Ilāha illa Allah" berarti menafikan otoritas dan petunjuk yang datang bukan dari Allah. Kalimat Tayyibāt itu berarti kalimat pembebasan bagi manusia. Dengan tauhid, manusia tidak saja bebas dan merdeka, melainkan juga akan sadar bahwa kedudukannya sama dengan manusia lain manapun (Rais, 1989:15). 
Manusia sejak lahir memperoleh kemerdekaannya tanpa seseorangpun mengikatnya. Satu-satunya perjanjian yang dibuat adalah untuk mengakui kebenaran mutlak tentang pengakuan bahwa Allah sajalah yang menjadi "Rabb" bagi dirinya, sebagaimana firman Allah dalam QS. al-A'rāf/7: 172 sebagai berikut:

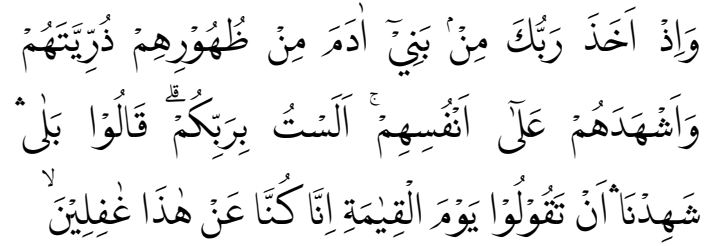

"Dan (ingatlah), ketika Tuhanmu mengeluarkan keturunan anak-anak Adam dari sulbi mereka dan Allah mengambil kesaksian terhadap jiwa mereka (seraya berfirman): "Bukankah aku ini Tuhanmu?" mereka menjawab: "Betul (Engkau Tuban kami), Kami menjadi saksi". (kami lakukan yang demikian itu) agar di hari kiamat kamu tidak mengatakan: "Sesungguhnya Kami (Bani Adam) adalah orang-orang yang lengah terhadap ini (keesaan Tuhan)" (QS. al-A'rāf/7: 172)

Perjanjian dengan Tuhan itu dibuat untuk menyatakan behwa hanya Allah sajalah yang berhak untuk disembah sedangkan yang lain tidaklah berhak untuk itu. Kenyataan ini menunjukan bahwa manusia lahir dalam keadaan merdeka, tidak menjadi budak siapapun dan mempunyai derajat yang sama dengan manusia yang lain. Dengan demikian, maka tauhid atau pengakuan keesaan Allah itu dapat mempengaruhi kepribadian seseorang, yaitu kepercayaan bahwa dirinya itu merdeka atau bebas dari intervensi orang lain secara mental (al-Zuhayli, 1991:157). e. Tauhid membentuk kepribadian optimis

Orang yang beriman kepada Allah adalah orang kuat. la memiliki kekuatan batin dan jiwanya, sehingga tidak pernah gentar menghadapi hidup dengan berbagai percobaannya. Kekuatan orang yang beriman diperoleh karena harapan kepada Allah. Dia tidak mudah putus asa, karena dia yakin bahwa Allah selalu menyertainya. Seseorang akan merasa tenang setelah mengetahui bahwa Tuhan dekat, mengabulkan permohonan orangorang yang bermohon kepadan- Nya, menerima taubat orang-orang yang bertaubat, menolong orang-orang yang teraniaya. Sesungguhnya rahmat Allah meliputi segala sesuatu.

Zakiyah Daradjat mengatakan bahwa, kesukaran yang paling sering dihadapi orang adalah kekesewaan. Kekecewaan yang terlalu sering dihadapi dalam kehidupan ini akan membawa orang kepada perasaan rendah diri, pesimis dan apatis dalam hidupnya; kekecewaan-kekecewaan yang dialaminya itu akan menggelisahkan jiwanya. Akan tetapi, hal itu berbeda dengan apa yang dialami orang yang beriman. Orangorang yang beriman dengan sungguhsungguh kepada Allah Swt. tidak mudah pesimis menghadapi kekecewaan-kekcewaan yang dialaminya. Mereka akan ingat kepada rahmat Tuhan yang telah diberikan. Dengan demikian, seorang yang bertauhid akan selalu optimis dalam menghadapi kehidupan ini (Daradjat, 1992:59).

Sesungguhnya, sikap optimis dalam hidup itu bersumber pada sikap berbaik sangka kepada Allah. Oleh karena itu, seharusnya orang yang beriman itu 
selalu berbaik sangka kepada Allah, walaupun mungkin seseorang mengalami musibah yang terasa berat baginya. Dengan begitu, jelaslah bahwa tauhid itu berpengaruh terhadap pengharapan atau sikap optimis. Sikap optimis erat kaitannya dengan rasa aman. Keduanya berpangkal dari kayakinan bahwa Allah itu Maha Penyantun, Pelindung serta Pemberi Rasa Aman. (Madjid, 1994:16)

Sikap optimis yang dimilki oleh seseorang sebagai implikasi dari keimanan seseorang kepada Tuhan akan menjadi tempat tumbuhnya sikapsikap positif lainnya, seperti rasa aman, sikap toleran, bersahabat, damai, dan tidak mudah berburuk sangka. Sikapsikap positif itu sangat diperlukan dalam kehidupan sehari-hari. Sikap optimis seseorng itu tumbuh, karena berpangkal dari keyakinan bahwa Allah itu Maha Pengampun, Pemberi rasa aman, Pelindung, dan sebaik-baik tempat bersandar dan seterusnya. Seseorang yang mempunyai ciri-ciri kepribadian seperti yang telah disebutkan di atas, adalah orang yang mempunyai kepribadian sempurna.

\section{PENUTUP}

\section{Simpulan}

Dari pemaparan yang telah dipaparkan, dapat ditarik kesimpulan bahwa ilmu pendidikan Islam sebagai sebuah disiplin ilmu harus senantiasa berpegang kepada prinsip-prinsip pendidikan islam yang bersumber dari Alquran, Hadis, ijmak dan kias. Hal itu disebabkan, karean apabila sebuah disiplin ilmu tidak memilki prinsip khususnya prinsip pendidikan Islam tersebut, maka dikahawatirkan akan terjadinya sekularisasi dan liberalisasi pendidikan.

Pendidikan Islam sebagai disiplin ilmu juga harus senantiasa mampu mengilmiahkan wawasan atau pandangan tentang kependidikan yang terdapat di dalam sumber-sumber pokoknya dengan bantuan dari pendapat para sahabat dan ulama/ilmuwan muslim. Oleh karenanya kita sebagai insan akademika yang terdapat dalam sebuah lembaga pendidikan harus lebih mengoptimalkan daya fikir dan mental untuk menatap pendidikan ke depan yang lebih maju.

\section{Rekomendasi}

Melihat fenomena pengaruh pendidikan terhadap pembentukan karakter hususnya di Indonesia saat ini, sudah saatnya lembaga pendidikan Islam kembali menguatkan dasar-dasar dan prinsip-prinsip pendidikan berdasarkan Alquran dan Hadits. Pendidikan Islam menitikberatkan bahwa inti dari pendidikan adalah menanamkan aqidah tauhid yang kuat bagi peserta didik, untuk mempersiapkan peserta didik mencapai kesuksesan hidup di dunia dan akhirat. 


\section{DAFTAR PUSTAKA}

'Abdullah Al-Mirgani, Al-Imam Muhammad 'Usman. (2009). Taaju at- Tafaasiir (Mahkota Tafsir). Bandung: Sinar Baru Algensindo,

Abrasyi, Muhammad Athiyah. (1996). Beberapa Pemikiran Pendidikan Islam. Yogyakarta: Titipan llahi Press

Al-Attas, Muhammad Naquib. (1984). Konsep Pendidikan dalam Islam. Bandung: Mizan.

Al-Ghazali, Muhammad. (1991). Abu Hamid, Ihya' 'Ulum al-Din, Jilid I, Semarang: Toha Putra Nasution Harun, Manusia Menurut Konsep Islam. Jakarta: Bulan Bintang

Al-Qâsimi, Muhammad Jamaluddin, Tafsir Mahâsin al-Ta'wîl, juz I. Kairo: Dar Ihya' al- Turats.

Ali, Attabik dan Muhdlar, Muh. Zuhdi. (1996). Kamus al-'Ashry. Yogjakarta: Muassasah Ali Maksum.

Nasir, Salihun. (2002). Peranan Pendidikan Agama Terhadap Pemecahan Problema Remaja. (Cet-3). Jakarta: Kalam Mulia.

An-Nahlawi, Abdurrahman. (1996). Prinsip-Prinsip dan Metoda Pendidikan Islam Dalam Keluarga, di Sekolah dan di Masyarakat. Bandung: CV. Diponegoro

Arifin, Muzayyin. (2010). Filsafat Pendidikan Islam. Jakarta: PT Bumi Aksara,

Daradjat, Zakiyah. (1992). Peranan Agama dalam Kesehatan Mental. Jakarta: Bumi Aksara.

Dewantara, Ki Hajar. (1967). Masalah Kebudayaan: Kenang-kenangan Promosi Doctor Honoris Causa. Yogyakarta

Gani, Bustami. (1990). Alquran dan Tafsirnya. Yogyakarta: PT. Dana Bhakti Wakaf UII.

Ghazali, Imam. (1995). Mukhtashar Ihya' Ulumuddin. Jakarta: Pustaka Amani.

Hasan, Muhammad Tholhah. (2005). Islam dan Masalah Sumber Daya Manusia. Jakarta: Lantabora Press.

Lajnah Pentashihan Mushaf Alquran. (2010). Tafsir Alquran Tematik. Jakarta: Lajnah Pentashihan Mushaf Alquran

Langgulung, Hasan. (1988). Asas-Asas Pendidikan Islam. Jakarta: Pustaka al-Husna,

Majid, Abdul dan Muhaimin. (1993). Pemikiran Pendidikan Islam. Bandung: Trigenda Karya

Madjid, Nurcholis. (1994). Pintu-pintu Menuju Tuhan. Jakarta: Yayasan Wakaf Paramadina

Marimba, Ahmad D. (1989). Pengantar Filsafat Pendidikan Islam. Bandung : Al-Ma'arif.

Maksum, Imam. (2009). Pendidikan Islam dan Globalisasi (Reaktualisasi Tujuan Pendidikan Islam Sebagai Upaya Meminimalisir Problematika Bangsa). Tulung Agung: Sumenang Kediri

Muthahhari, Murtadha. (1992). Allah fi Hayat al-Insan. terjemah Agus Efendi dengan Allah dalam Kehidupan Manusia. Bandung: Mizan

Mutammam. (2007). Mengembangkan Tingkat Kualitas Pendidikan Dasar: Sebuah Analisis Pnedidikan Sebagai Investasi. Yogyakarta: Gama Media

Najati, M. Utsman. (1402 H). Alquran wa 'llm al-Nafs. Kairo: Dar al-Syuruq 
Nasir, Salihun. (2002). Peranan Pendidikan Agama Terhadap Pemecahan Problema Remaja. Jakarta: Kalam Mulia.

Nasution, Harun. (1991). Pembaharuan Dalam Islam; Sejarah Pemikiran dan Gerakan. Jakarta: Bulan Bintang.

Nata, Abudin. (2005). Pendidikan dalam Perspektif Alquran. Jakarta: UIN Jakarta Press

Nizar, Samsul. (2001). Dasar-Dasar Pemikiran Pendidikan Islam. Jakarta: Gaya Media Pratama

Ramayulis. (2013). Ilmu Pendidikan Islam. (Cet. Ke-10). Jakarta: Kalam mulia

Saiyidain, K.G. (1986). Iqbal's Educational Philosophy. Terjemah M.I. Soelaeman, Percikan Filsafat Iqbal Mengenai Pendidikan. Bandung: Diponegoro.

Siradz, Said Aqil. (2003, 10 September). Reposisi Kependidikan Islam: Telaah Implementasi UU Sisidiknas Tahun 2003. Makalah disampaikan dalam seminar sehari yang diselenggarakan oleh STAI NU di Jakarta

Tim Dosen FIP-IKIP Malang, Pengantar Dasar-Dasar Pendidikan, Surabaya, Usaha Nasional

Tim Penyusunan Kamus Pusat dan Pembinaan dan Pengembangan Bahasa. (1994). Kamus Besar Bahasa Indonesia. Jakarta: Balai Pustaka

Tim Penulis. (1992). Ensiklopedi Islam Indonesia. Jakarta: Djambatan. 